\title{
Optimalisasi Pelayanan Haji dalam Meningkatkan Kepuasan Jamaah
}

\author{
Resti Wildayati ${ }^{{ }^{*}}$, Dindin Solahudin ${ }^{2}$, Arif Rahman ${ }^{3}$ \\ ${ }^{1}$ Jurusan Manajemen Dakwah, Fakultas Dakwah dan Komunikasi, UIN Sunan Gunung Djati, \\ Bandung \\ ${ }^{2} J u r u s a n$ Pengembangan Masyarakat Islam, Fakultas Dakwah dan Komunikasi, UIN Sunan \\ Gunung Djati, Bandung \\ *Email : restim@student.uinsgd.ac.id
}

\begin{abstract}
This study aims to determine the from, responsiveness and guarantee in increasing satisfaction given by the Hajj and Umrah Organization of the Ministry of Religion of Karawang district in an effort to increase the satisfaction of the pilgrims. In order to answer the problem as follows: how the form of service fasilities, responsiveness in helping and guarantee in increasing the satisfaction of worshipers. This study uses a qualitative methode with a descriptive approach with data collection techniques used in observation, interview and documentation techniques. The results of this study indicate that the optimalization of Haij services in increasing congregation satisfaction can be concluded that (1) the form of service facilities in the field of organizing Haij and Umrah is sufficiently proven as evidended by the convenience of providing service, adequate use of technology and supporting onte-stop pilgrimage services can facilitate, (2) Responsiveness in helping and providing service is carried out by placing staaf in accordance with the expertien of each, (3) Guarantees provided in creasing satisfaction are carried out through administrative guarantees, security and scientic.
\end{abstract}

Keywords:Service; Haij and Satisfaction

\begin{abstract}
ABSTRAK
Penelitian ini bertujuan untuk mengetahui wujud, ketanggapan dan jaminan dalam meningkatkan kepuasan yang diberikan oleh Penyelenggaraan Haji dan Umrah kementerian agama kabupaten karawang dalam upaya meningkatkan kepuasan jamaah haji. Dalam rangka menjawab permasalahan sebagai berikut: bagaimana wujud fasilitas pelayanan, ketanggapan dalam membantu dan jaminan dalam meningkatkan kepuasan jamaah. Penelitian ini menggunakan metode kualitatif dengan pendekatan deskriptif dengan teknik pengumpulan data yang digunakan teknik observasi, wawancara dan dokumentasi. Hasil penelitian ini menunjukan bahwa optimalisasi pelayanan haji dalam meningkatkan kepuasan jamaah dapat ditarik kesimpulan bahwa (1) Wujud fasilitas pelayanan di bidang penyelenggaran haji dan umrah sudah memadai terbukti dengan adanya
\end{abstract}


kenyamanan tempat dalam memberikan pelayanan, penggunaan teknologi yang memadai dan adanya penunjang pelayanan haji satu atap yang dapat memudahkan, (2) Ketanggapan dalam membantu dan menyediakan pelayanan dilakukan dengan menempatkan staff sesuai dengan keahlian masing-masing staff, (3) Jaminan yang diberikan dalam meningkatkan kepuasan dilakukan dengan melalui jaminan administrasi, jaminan keamanan dan jaminan keilmuan.

Kata Kunci :Pelayanan; Haji; dan Kepuasan;

\section{PENDAHULUAN}

Menunaikan ibadah haji merupakan rukun islam yang ke lima dan wajib hukumnya bagi setiap muslim yang mampu, ibadah haji tidak hanya ibadah yang mengorbankan harta tetapi ibadah yang mengorbankan jasmani dan rohani, tujuan ibadah haji bukanlah semata-mata mengunjungi Makkah ataupun Madinah dan bukan pula karena wukuf, thawaf maupun sa'i tetapi tujuan yang sebenarnya adalah mencari ridha Allah Swt. Dalam beribadah haji dan umrah tentunya ada tata cara dalam melaksanakannya diantaranya ialah: adanya syarat, rukun dan wajib hanya saja ada perbedaan diantara tata cara haji dan umrah seperti pelaksanaan wukuf di arafah, mabit di mina, mabit di muzdalifah dan melontar jumroh,dalam beribadah haji tidak ada perbedaan kasta dan juga suku bangsa, tidak ada diskriminasi dan tidak ada pula perbedaan warna kulit, dalam undang-undang negara republik indonesia tahun 1945 pasal 29 ayat 2 menyatakan bahwa negara menjamin kemerdekaan tiap-tiap penduduk untuk memeluk agamanya masing-masing dan untuk beribadah menurut agama dan kepercayaannya. Indonesia merupakan sebagai salah satu negara yang memiliki jumlah penduduk yang beragama islam terbesar di dunia dalam melakukan penyelenggaraan ibadah haji di setiap tahunnya, sehigga dasar dan hukum dalam pelaksanaan penyelenggaraan ibadah haji ditetapkan dalam undang-undang nomor 13 tahun 2008 tentang penyelenggaraan ibadah haji.

Kementerian agama merupakan suatu lembaga pemerintah yang memiliki legalitas dalam memberikan pelayanan bagi setiap masyarakat (muslim) sesuai dengan haknya sebagai warga negara menjadi tugas pemerintah salah satunya adalah penyelenggaraan ibadah haji dan umrah yang dikoordinasikan oleh Menteri agama dalam undang-undang nomor 13 tahun 2008 bahwa pemerintah berkewajiban melakukan pembinaan, pelayanan dan perlindungan dengan menyediakan layanan administrasi, bimbingan ibadah haji, akomodasi, transportasi, pelayanan kesehatan, keamanan dan hal-hal lain yang diperlukan oleh jamaah haji. Agar jamaah haji dapat menunaikan ibadah haji dengan aman, nyaman dan lancer sesuai dengan ajaran agama islam, maka penyelenggaraan haji dan umrah berkewajiban memberikan pembinaan, pelayanan dan perlindungan dengan sebaik-baiknya kepada jamaah haji, penyelenggaraan ibadah haji 
dilakukan berdasarkan asas keadilan di implementasikan dengan memberikan pelayanan sesuai hak jamaah haji tanpa mengurangi sedikitpun oleh lembaga kepada jamaahnya, professional dan akuntabilitas dengan prinsip nirlaba yaitu tidak mencari keuntungan tetapi mementingkan pelayanan, dalam memberikan pelayanan yang dilakukan oleh penyelengggaraan haji dan umrah harus mampu melakukan manajerial yang tepat disegala aspek, karena seksi penyelenggaraan haji dan umrah memiliki tugas dalam memberikan pelayanan kepuasan kepada jamaah haji dengan memenuhi kebutuhan, keinginan dan harapan jamaah, fungsi tersebut merupakan bagian penting untuk menghadapi persaingan, pelayanan sangat mempengaruhi kepuasan jamaah haji, jika pelayanan yang diberikan dirasa sesuai dengan harapan calon jamaah haji maka secara tidak langsung dapat memuaskan jamaah haji, sedangkan apabila harapan jamaah haji tidak dapat terpenuhi maka pelyanan dinilai tidak dapat memuaskan dan apabila pelayanan haji yang diberikan melebihi harapan maka pelayanan tersebut dirasa sangat memuaskan jamaah haji. Oleh karena itu, strategi keberhasilan yang dilakukan oleh penyelenggaraan haji dan umrah ditentukan oleh kemampuan dalam memberikan pelayanan yang berkualitas terhadap kepuasan calon jamaah haji.

Secara umum pelayanan ditandai dengan kemilikan cara ataupun mekanisme yang memberikan kemudahan baik dalam mengakses informasi maupun penggunaan fasilitas yang diberikan lembaga (Sungkar \& Fitriyani, 2016); Kualitas pelayanan, penanganan komplain, dan fasilitas teknologi berpengaruh signifikan terhadap kepuasan (Sulistyowati, M.\& Hreawati, 2019). Demikian pula dalam pelayanan jamaah haji dalam KBIH.

Menurut Zeithaml, kualitas pelayanan harus didasari lima dimensi, yaitu tangible (wujud), reliability (kehandalan), responsiveness (ketanggapan), assurance (jaminan) dan emphaty (empati). Sedangkan ciri-ciri pelayanan yang baik yang dapat memberikan kepuasan bagi jamaah haji adalah memilik karyawan yang professional, tersedianya sarana dan prasaranan yang baik, bertanggung jawab kepada setiap jamaah dari awal hingga selesai, mampu melayani secara tepat, mampu berkomunikasi secara jelas dan mampu memberikan kepercayaan kepada jamaah(Hardiyansyah, 2011:46). Berdasarkan dari hasil wawancara yang dilakukan pada studi pendahuluan adalah bahwa adanya peningkatan jumlah jamaah haji, sehingga bagaimana bidan penyelenggaraan haji dan umrah dapat memerikan pelayanan dalam meningkatkan kepuasan dengan adanya peningkatan jamaah haji.

Adapun penelitian sebelumnya yang disusun oleh Ramadoni (2013) yang berjudul pelayanan KBIH Darut Tauhid dalam memfasilitasi calon jamaah haji, bahwa pelayanan merupakan salah satu aspek terpenting yang harus diperhatikan oleh setiap lembaga, kaitannya dengan ibadah haji, banyak sekali permasalahan- 
permasalahn yang muncul akibat dari pelayanan, contohnya pelayanan dalam manasik haji, tidak sedikit KBIH hanya memenuhi kebutuhan calon jamaah haji dari segi materinya saja, sedangkan aplikasinya tidak diperhatikan. Hasil dari penelitian ini penulis memperoleh gambaran mengenai ciri khas dan pelayanan dalam tataran standar kualitas yang tinggi serta proses pemeriksaan dalam tataran kebutuhan praktis di KBIH darut tauhid.

Berdasarkan aturan, tentang pengelolaan ibadah haji diteliti oleh Fanham (2015); Penyelenggaraan Ibadah Haji: Masalah Dan Penanganannya. Hasilnya menunjukkan bahwa materi muatan yang perlu direvisi antara lain mengenai pembatasan pendaftar haji, organisasi penyelenggara, panitia penyelenggara, petugas haji, dan biaya penyelenggaraan ibadah haji.

Sedangkan Nidzam (2015) melakukan penelitan dari aspek prosedur pendaftaran yang relevansi dengan pelayanannya sangat kuat. Hasilnya menunjukkan bahwa proses rekayasa ulang serta rancangan baru prosedur pendaftaran haji lebih baik dari sistem lama terkait dengan beberapa aspek pelayanan dalam penyelenggaraan haji.

Penelitian lainnya dilakukan oleh Susilawati, Sarbini, dan Setiawan (2016), hasil penelitiannya adalah bahwa implementasi fungsi manajemen dalam pelayanan yang diberikan oleh KBIH Bustanul Wildan terhadap tingkat kualitas calon jamaah terdiri dari fungsi manajemen, yang terdiri dari perencanaa, pengorganisasian, pelaksanaan dan evaluasi.

Berdasarkan konsep kepuasan, pernah diteliti oleh Jaya (2013) tentang Tingkat Kepuasan Jemaah Haji Kota Medan Terbadap Pelayanan Haji Tabun 2012. Berdasarkan hasil analisis didapatkan tingkat kepuasan peziarah kota haji dengan bidang jasa pada tahun 2012 adalah puas bahwa persentase 70,7\%, yang berarti bahwa peziarah puas dengan layanan asrama haji daerah pada tahun 2012. Sementara itu, untuk meningkatkan kepuasan peziarah haji pihak asrama harus meningkatkan kinerja di lapangan atribut kemampuan perawat pada saat memberikan layanan kepada para peziarah, yang perhatian pejabat dalam menangani jamaah haji, dan perawatan jamaah haji ke asrama haji.

Kepuasan tentang pelayanan jamaah haji juga diteliti oleh Khoiruddin, Hanafi, dan Rozikin (2015) tentang Pengarub Reformasi Organisasi Pengelolaan Pelayanan Haji Terbadap Kepuasan Jamaah Haji. Hasilnya menunjukkan bahwa Reformasi Organisasi Pengelolaan Pelayanan Haji memiliki pengaruh yang signifikan secara simultan dan parsial terhadap kepuasan jamaah Haji.

Perbedaan penelitian ini dengan penelitian sebelumnya ialah bahwa dalam sebuah lembaga penyelenggaraan ibadah haji harus memiliki kualitas pelayanan yang baik agar dapat memenuhi kepuasan jamaah sehingga para jamaah terus menggunakan jasa dari lembaga penyelenggaraan ibadah haji. Hasil 
penelitian ini menunjukan bahwa kementerian agama khususnya seksi penyelenggaraan haji dan umrah memiliki peran yang sangat penting dalam penyelenggaraan ibadah haji sehingga peneliti memperoleh gambaran tentang tangible (wujud) fasilitas pelayanan, responsiveness (ketanggapan) dalam membantu melayani secara sigap kepada jamaah, assurance (jaminan) yang diberikan oleh penyelenggaraan haji dan umrah dapat meningkatkan kepuasan jamaah.

Penelitian ini dilaksanakan di Kementerian Agama Kabupaten Karawang di Bidang Penyelenggaraan Haji dan Umrah (PHU) yang beralamat di Jl. Husni Hamid No. 1 Karawang.

Adapun pertanyaan penelitian yang diajukan kepada kepala seksi dan staff penyelenggaraan haji dan umrah di kementerian agama karawang untuk menjawab fokus penelitian: (1) Bagaimana profil kementerian agama kabupaten karawang?.(2) program kerja apa saja yang ada di Penyelenggaran Haji dan Umrah (PHU) ?. (3) Bagaiaman penyelenggaraan haji dan umrah dalam meningkatkan pelayanan kepada calon maupun jamaah hji?.(4) Hambatan serta solusi apa yang dilakukan untuk meningkatkan pelayanan kepada jamaah haji?.(5) Bagaimana standar pelayanan yang diterapkan oleh PHU?.(6) Bagaimana sistem atau tata cara pendaftaran haji di PHU?.(7) Pelayanan apa saja yang diberikan kepada calon/jamaah haji?.(8) Bagaiaman sarana dan prasarana pendukung dalam memberikan pelayanan haji di PHU?.(9) Bagaimana ketanggapan PHU dalam membantu melayani jamaah haji?.(10) Jamninan apa yang diberikan untuk meningkatkan kepuasan?.

Metode penelitian pada penyususnan penelitian ini, penulis menggunakan pendekatan deskriptif kualitatif yaitu dengan melakukan penelitian untuk menghasilkan data berupa kata-kata tertulis atau lisan dari orang-orang dan perilaku yang diamati. Metode deskriptif ini digunakan sebagai cara praktis untuk mengumpulkan informasi, menjelaskan atau mengidentifikasi kondisi yang ada dilokasi penelitian dan menjabarkan tentang pelayanan ibadah haji dan umrah. Dengan menggunakan metode pendekatan deskriptif kualitatif peneliti akan menganalisis hasil pengumpulan data melalui observasi dan wawancara kepada kepala seksi dan staff penyelenggaraan haji dan umrah di kementerian agama kabupaten karawang.

\section{HASIL DAN PEMBAHASAN}

Fokus pembahasan dalam landasan teoritis pada penelitian ini akan dipaparkan mengenaipelayanan, haji dan kepuasan. Pada dasarnya, setiap manusia membutuhkan pelayanan, bahkan secara ekstrimpelayanan tidak dapat dipisahkan dengan kehidupan manusia. Untuk memenuhi kehidupannya manusia berusaha melalui aktivitas sendiri maupun aktivitas orang lain untuk 
mendapatkan pelayanan yang diinginkan. Proses pemenuhan kebutuhan melalui aktivitas sendiri maupun aktivitas orang lain inilah yang dinamakan pelayanan. Pelayanan bukan hanya mendengarkan dan menjawab keluhan konsumen, tetapi lebih dari itu pelayanan yang berkualitas merupakan saran untuk mengidentifikasi dan memenuhi kebutuhan konsumen (Lyhe, 1996: 118). Berkaitan dengan pelayanan ada dua istilah, yaitu: melayani dan layanan. Pengertian pelayanan adalah pekerjaan pelayan, yaitu membantu menyiapkan apa-apa yang diperlukan seseorang atau melayani seseorang. Sedangkan layanan adalah kata benda yang berarti perihal atau cara melayani. Berikut beberapa pengertian pelayanan menurut para ahli, diantaranya:

Menurut Lovelock, service adalah produk yang tidak berwujud, berlangsung sebentar dan dirasakan atau dialami. Artinya pelayanan merupakan produk yang tidak ada wujud atau bentuknya sehingga tidak ada bentuk yang dimiliki dan berlangsung sesaat atau tidak lama, tetapi dialami dan dapat dirasakan oleh penerima layanan (Rewansyah, 2011:52). Sianipar, pelayanan adalah cara melayani, menyiapkan, mengurus dan menyelesaikan keperluan/kebutuhan individu dan sekelompok orang, artinya objek yang dilayani adalah individu/pribadi dan kelompok organisasi (Rewansyah, 2011: 52).

Pelayanan adalah bentuk pemberian yang diberikan oleh produsen baik terhadap pelayanan barang yang diproduksi maupun terhadap jasa yang ditawarkan guna memperoleh minat konsumen, dengan demikian pelayanan mempengaruhi minat konsumen terhadap suatu barang atau jasa dari pihak perusahaan yang menawarkan produk atau jasa. Dari uraian ini, maka pelayanan dapat diartikan sebagai aktivitas yang diberikan untuk membantu menyiapkan dan mengurus baik dalam bentuk atau jasa dari satu pihak kepada pihak lain.

Adapun bentuk layanan umum tidak terlepas dari tiga bentuk layanan, ketiga bentuk tersebut diantaranya: Layanan dengan Lisan, digunakan oleh bidang HUMAS, bidang informasi dan bidang lain yang bertugas memberikan penjelasan kepada siapapun yang memerlukan. Layanan Melalui Tulisan merupakan bentuk pelayanan yang penting dalam melaksanakan tugas baik sebuah lembaga atau organisasi, pada dasarnya pelayanan melalui tulisan dianggap efisien terutama bagi pelayanan jarak jauh. Layanan Berbentuk Perbuatan, dilakukan oleh petugas baik tingkat menengah maupun tingkat bawah, dalam sehari-hari jenis pelayanan tidak pernah terhindar dari pelayanan lisan, pelayanan perbuatan dan pelayanan lisan sering bergabung hal ini disebabkan karena hubungan lisan paling banyak dilakukan dalam hubungan pelayanan secara umum (Moenir, 2010: 190).

Kata haji menurut bahasa ialah Al-Qashdu artinya bermaksud. Dalam arti lain haji ialah sengaja mengunjungi kabah atau baitullah untuk melakukan 
beberapa amalan ibadah dengan syarat-syarat tertentu, yakni mengerjakan thawaf, sa'i, wukuf dan manasik haji dengan mengikuti tuntunan Rasulullah SAW. Kewajiban melaksanakan ibadah haji adalah wajib bagi seseorang yang sudah mampu, baik secara biaya, sehat jasmani dan rohani. Allah berfirman, yang artinya: "Disana terdapat tanda-tanda yang jelas, (diantaranya) maqam Ibrahim. Barang siapa memasukinya amanlah dia. Dan (diantara) kewajiban manusia terhadap Allah adalah melaksanakan ibadah haji ke Baitullah, yaitu bagi orangorang yang mampu mengadakan perjalanan kesana. Barang siapa mengingkari (kewajiban) haji, maka ketahuilah bahwa Allah Mahakaya(tidak memerlukan sesuatu) dari seluruh alam.” (Q.S. Ali Imran, 4: 97) (Al-Quran al-Hadi, 2008. Jakarta: Pusat Kajian Hadis).

Sabda Rasulullah SAW:

"Wahai manusia, bahwasanya Allah telah mewajibkan atas kamu sekalian beribadah haji, maka hendaknya kalian mengerjakan haji”. Maka bertanya seorang laki-laki: Apakah tiap tahun ya Rasulullah?. Maka beliau diam tak berbicara, sehingga seorang itu bertanya lagi samapi tiga kali. Lalu Nabi SAW bersabda: "Andai kata saya menjawab "ya" pasti menjadi wajib tiap-tiap tahun, sedang kalian tidak akan mampu melaksanakannya" (HR. Ahmad, Muslim dan Nassa'i).

Dalam beribadah haji tentunya terdapat rukun dan wajib haji yang harus dilaksanakan, diataranya: rukun haji adalah sesuatu yang tidak sah haji melainkan dengan melakukannya dan ia tidak boleh diganti dengan dam (menyembelih binatang) (Rasjid, 2014: 257). Jadi apabila rukun haji ditinggalkan maka hajinya tidak sah, sedangkan wajib haji adalah rangkaian amalan yang harus dilaksanakan dalam haji. Apabila ditinggalkan, hajinya sah tetapi harus membayar dam dan berdosa apabila sengaja melanggarnya tanpa ada udzur syar'i. Macam-macam pelaksanaan ibadah haji atau ansakul Hajj ada tiga, yaitu: Haji Ifrad yaitu berihram untuk haji saja. Haji tamattu yaitu berihram untuk melaksanakan umrah pada bulan-bulan haji dan bertahalull darinya, kemudian berihram kembali untuk haji pada tahun ini. Haji Qiran yaitu berihram untuk melaksanakan haji dan umrah secara bersama atau berihram untuk umrah kemudian memasukkan niat haji sebelum ia memulai thawaf umrah, sedangkan yang memilih pelaksanaan seperti haji ifrad umumnya ia tidak dikenai dam/denda berupa seekor kambing, sedangkan haji tamattu dan haji qiran diwajibkan membayar dam berupa seekor kamibng yang disembelih pada hari penyembelihan (Taufiqurrochman, 2011: 8).

Kepuasan merupakan suatu tingkatan dimana keinginan, kebutuhan dan harapan dari pelanggan dapat terpenuhi oleh lembaga yang mengakibatkan baik pembeli secara ulang maupun setia dalam memakai produkyang ditawarkan oleh lembaga. Kata statisfication (kepuasan) berasal dari bahasa latin, yaitu "statis" 
yang berarti cukup baik dan kata "facio" yang berarti melakukan atau membuat (Rahmayanti, 2010: 17).

Menurut Kolter kepuasan adalah tingkat perasaan senang atau kecewa seseorang yang muncul setelah membandingkan kinerja atau hasil suatu produk yang dipikirkan terhadap kinerja atau hasil yang diharapakan (Tjiptono, 2006: 146). Hal ini menunjukan bahwa kepuasan pelanggan merupakan suatu pemenuhan harapan, terciptanya kepuasan pelanggan dapat memberikan berbagai manfaat, diantaranya hubungan antara pelanggan dan pemberi layanan menjadi harmonis, sehingga memberikan dasar yang baik bagi terciptanya loyalitas pelanggan, membentuk suatu rekomendasi dari mulut ke mulut (word of mouth) yang menguntungkan bagi pemberi layanan, reputasi yang semakin baik dimata pelanggan, serta laba yang diperoleh akan semakin meningkat. Menurut Kolter ada beberapa metode yang dapat digunakan oleh perusahaan untuk mengukur dan memantau kepuasan pelanggan, yaitu: Sistem Keluhan dan saran (Complaint and Suggenstion System). Survei Kepuasan Pelanggan (Customer Statisfication Surveys). Pembeli Bayangan (Ghost Shoping). Analisis Pelanggan yang Beralih (Lost Customer Analysis).

Ada beberapa faktor-faktor yang dapat membengaruhi kepuasan konsumen diantaranya, kinerja pelayan terhadap pelanggan, kinerja staff pelayan terhadap kepuasan pelanggan, kepuasan konsumen ditinjau dari sisi aspek layanan yang diterima (Kirom, 2015: 193). Sedangkan menurut Irawan dalam menentukan kepuasan pelanggan ada lima faktor yang harus diperhatikan oleh setiap lembaga, diantaranya yaitu, kualitas produk, harga, servive quality, emotional factor, biaya dan kemudahan (Irawan, 2004: 37).

Penelitian ini dilakukan di Kementerian Agama Kabupaten Karawang, yang beralamat di jl. husni hamid no 1 karawang. Rute menuju kementerian agama kabupaten karawang ini dapat ditempuh dengan menggunakan kendaraan roda dua maupun roda empat adapun lokasi kementerian agama kabupaten karawang ini cukup mudah ditemukan karena berada di dekat area kantor pemerintahan bupati kabupaten karawang. Kementerian agama kabupaten karawang merupakan salah satu satuan kerja yang berada dibawah dan bertanggung jawab kepada kepala seksi yang berada di kementerian agama terutama penyelenggaraan haji dan umrah. Adapun tugas dan fungsi kementerian agama kabupaten karawang diantaranya yaitu: Rumuskan visi dan misi serta kebijakan tertulis di bidang pelayanan dan bimbingan kehidupan beragama kepada masyarakat. Melaksanakan pembinaan pelayanan dan bimbingan di bidang bimbingan masyarakat islam, pelayanan haji dan umrah, pengembangan zakat dan wakaf, pendidikan agama dan keagamaan, pondok pesantren, pendidikan agama islam pada masyarakat dan pemberdayaan masjid sesuai peraturan yang berlaku. Melaksanakan kebijakan teknis di bidang 
pengelolaan administrasi keagamaan. Melaksanakan pelayanan dan pengembangan kerukunan umat beragama. Melaksanakan perencanaan, [engendalian, pengawasan program. Menjalin hubungan dengan pemerintah daerah, instansi terkait dan lembaga masyarakat dalam rangka pelaksanaan tugas.

Visi, misi dan tujuan merupakan hal yang sepele, ringkas tidak membutuhkan modal dan tenaga untuk membuatnya, tetapi keberadaan ini menjadikan suatu hal yang sacral dan berkontribusi besar dalam pengembangan sebuah lembaga atau organisasi (Kusnawan, A., Rahman, A., Lukman, D. \& Dulwahab, E. 2017: 285). Karena visi misi merupakan koridor dan Batasanbatasan yang menangani langkah-langkah, gerak dan orientasi dalam menjalakan tugas dan fungsi sebagai membantu pemerintahan dalam penyelenggaraan ibadah haji, dalam memberikan sebuah pelayanan kepada masyrakat kabupaten karawang, khusunya seksi penyelenggaraan haji dan umrah kementerian agama kabupaten karawang pun tentunya memiliki visi dan misi. Demikian juga kementerian agama harus memiliki input perangkat yaitu struktur organisasi, struktur organisasi ini sangat penting dalam mempengaruhi perilakuk dalam struktur, dimana struktur organisasi adalah suatu tugas yang diterima oleh setiap personalia dengan siapa mereka bekerja sama dengan siapa mereka berinteraksi dan kepada siapa mereka melaporkan hasil pekerjaannya tersebut. Adapun struktur organisasi tata kerja kementerian agama kabupaten sebagai berikut: Kepala kantor kementerian agama, Kepala Sub bagian Tata Usaha, Kepala Seksi Pendidikan Madrasah, Kepala Seksi Pendidikan Diniyah dan Ponpes, Kepala Seksi Pendidikan Agama Islam, Kepala Sekis Penyelenggaraan Haji dan Umrah, Kepala Seksi Bimas, Penyelenggaraan Syariah. Tata cara pendaftaran haji regular dilakuakn melalui prosedur sebagai berikut: Pertama, Pendaftaran dilakukan pada hari kerja sepanjang tahun di kantor kementerian agama kabupaten atau kota sesuai dengan domisili, wajib dilakukan oleh sendiri untuk mengambil foto dan sidik jari, pendaftaran merupakan prinsip awal bil awal (mendaftar pertama di layani pertama), calon jamah haji yang sudah menunaikan haji baru bisa mendaftar setelah sepuluh tahun sejak menunaikan ibadah haji terakhir.Kedua, Alur Pendaftaran, calon jamaah haji datang ke Bank Penerima Setoran (BPS) untuk membuka rekening tabungan haji dan menyetorkan uang setoran awal BPIH ke rekening menteri agama lalu menerima bukti BPIH lembar 1,3,4 dan 5 yang diberi foto dicap dan ditanda tangani BPS dan diberi nomor validasi, calon jamaah haji datang kekantor kementerian agama kabupaten/kota setempat tanpa di wakilkan paling lambat lima hari kerja setelah menyetorkan setoran awal BPIH untuk menyerahkan bukti lembaran setoran BPIH lembar 3,4 dan 5 serta seluruh persyaratan, mengisis surat pergi haji difoto dan disidik jari untuk pendaftaran ke dalam SISKOHAT, menerima bukti pendaftaran haji yang telah 
ditanda tangani dan dicap dinas kementerian agama dan mendapatkan nomor porsi.

Adapun rangkaian kegiatan dari penyelenggaran haji dan umrah kementerian agama kabupaten karawang adalah sebagai berikut: pertama, Persiapan, persiapan ini telah mengadakan langkah-langkah yaitu membangun gedung pelayanan haji satu atap guna memudahkan dan mempercepat pelayanan pendaftaran calon jamaah haji yang diprakasai oeh FK KBIH yang bekerja sama dengan BPS-BPIH dan bank muamalat, bank permata Syariah, bank CIMB syriah dan bank panin dubai Syariah. Mengadakan sosialisasi sistem pendaftran haji satu atap sepanjang masa dengan bank penerima setoran BPIH, kepala Kantor Urusan Agama (KUA) kecamatan, penyuluhan agama dan ketua Kelompok Bimbingan Ibdah Haji (KBIH) sekabupaten karawang. Mengikuti rapat persiapan yang diselenggarakan oleh kantor wilayah. Menyelenggarakan rapat persiapan penyelenggaraan urusan haji dengan instansi yang terkait. Kedua, Pelaksnaan, ada beberapa pelaksanaan diantaranya sebagai berikut, (1) Pendaftaran, (2) Pemeriksaan Kesehatan berdasarkan peraturan menteri kesehatan republik Indonesia nomor 15 tahun 2016 tentang isthithaah kesehatan calon jamaah haji, pemeriksaan jamaah haji dilakukan dalam beberapa tahapan yaitu, pemeriksaan kesehatan dipueskesmas setempat pada saat jamaah melakukan pendaftran untuk memperoleh nomor porsi, pemeriksaan kesehatan jamaah haji kabupaten dilakukan oleh tim penyelenggaraan kesehatan haji kabupaten di puskesmas atau rumah sakit, pemeriksaan oleh panitia Penyelenggaraan Ibadah Haji (PPIH)embarkasi bidang kesehatan pada saat menjelang keberangkatan di embarkasi, pelaksanaan vaksinasi minginitis dilakukan oleh dinas kesehatan yang dialokasi pada beberapa puskesmas yang di tunjuk. (3) Pelunasan BPIH. (4) Mutasi Calon Haji. (5) Pembatalan, pembatalan jamaah haji merujuk pada pemerintahan menteri agama nomor 14 tahun 2012 pasal 11, adapun persyaratan pembatalan haji terbagi tiga, yaitu: batal biasa, batal meninggal di tanah air dan meninggal di saudi arabia. (6) Proses Penyelesaian Administrasi dan Sarana diantaranya sebagai berikut: paspor, pramanifest dan buku paket dan seragam.

\section{Tangible (Wujud) Fasilitas Pelayanan di Bidang Penyelenggaraan Haji dan Umrah (PHU)}

Fasilitas merupakan sumber daya fisik yang harus ada sebelum suatu jasa yang ditawarkan kepada konsumen. Bukti fisik adalah bentuk aktualisasi nyata yang dapat dilihat atau digunakan oleh pegawai sesuai dengan penggunaan dan pemanfaatan yang dapat dirasakan untuk membantu pelayanan yang diterima oleh orang yang menginginkan pelayanan tersebut, sehingga merasakan kepuasan atas pelayanan yang dirasakan sekaligus untuk menunjukan prestasi kerja atas pemberian pelayanan yang diberikan oleh lembaga atau organisasi . 
Fasilitas sarana dan prasaranan merupakan salah satu komponen yang terpenting yang harus ada di dalam sebuah lembaga formal maupun non formal, sebab sarana dan prasarana merupakan salah satu faktor penunjang agar terlaksananya suatu pelayanan dalam sebuah lembaga atau organisasi, sarana dan prasaranan merupakan seperangkat alat yang dapat digunakan dalam suatu proses kegiatan baik peralatan pembantu maupun peralatan utama yang keduanya berfungsi untuk mewujudkan suatu tujuan yang ingin dicapai. Dengan adanya sarana dan prasarana tersebut dapat memberikan kemudahan dalam memberikan pelayanan terhadap jamaah haji, tetapi jika suatu proses kegiatan yang dilaksanakan tidak akan mencapai hasil yang diharapkan sesuai dengan rencana jika sarana dan prasarana tidak tersedia. Terkait dengan fasilitas yang terdapat di penyelenggaraan haji dan umrah kementerian agama kabupaten karawang sudah cukup memadai. Hal ini sebagaimana diungkapkan oleh bapak H. Odang selaku kepala seksi penyelenggaraan haji dan umrah beliau memaparkan bahwa:

"untuk fasilitas sarana dan prasarana yang dimiliki oleh kementerian agama khususnya seksi penyelenggaraan haji dan umrah sudah nyaman dan memadai seperti ruangan pendaftaran yang dimiliki penyelenggaraan haji dan umrah sudah nyaman dan ruangan yang cukup luas dan tersendiri" (wawancara pada hari senin, 4 Juni 2018).

Selain dari pada saranan dan prasarana yang diberikanjuga terdapat sarana dan prasarana yang lain untuk menunjang dalam segi memberikan pelayanan terhadap calon jamaah haji.Hal ini sebagaiman ditambahkan oleh bapak $\mathrm{H}$. Odang selaku kepala seksi penyelenggaraan haji dan umrah (PHU):

"selain itu ada juga Bank penerima setoran haji, penggunaan alat-alat teknologi yang memadai seperti komputer, kamera digital, pemotretan sidik jari, pemotretan SPPH (Surat Pendaftaran Pergi Haji) dan scanner ditambah dengan adanya Sistem Komputerisasi Haji Terpadu (SISKOHAT) untuk menunjang fasilitas sarana dan prasarana dari pelayanan haji satu atap yang ada di kemeterian agamakarena melihat calon jamaah haji yang sangat antusias untuk mendaftar haji hingga saat ini pendaftaran calon jamaah haji semakin meningkat" (wawancara pada hari senin, 4 Juni 2018).

Menurut Mudie dan Cattam dalam Tjiptono (2004: 26) mengatakan bahwa unsur-unsur yang perlu dipertimbangkan dalam menentukan fasilitas jasa ada enam, yaitu diantaranya: (1) pertimbangan atau perencanaan special. (2) perencanaan ruangan. (3) perlengkapan atau perabotan. (4) tata cahaya. (5) warna. (6) pesan-pesan yang disampaikan secara grafis. 
Berdasarkan dari hasil wawancara dengan kepala seksi penyelengggaraan haji dan umrah bahwa fasilitas dari sarana dan prasarana yang terdapat di kementerian agama khususnya di Penyelenggaraan Haji dan Umrah (PHU) sudah cukup memadai untuk memeberikan pelayanan kepada calon jamaah haji. Hal ini dapat dirasakan oleh calon jamaah haji itu sendiri, dimana kenyamanan ruangan yang sejuk dan luas yang dirasakan oleh calon jamaah haji, tidak hanya ruangan tetapi saranan dan prasarana penunjang dalam segi pelayanan pun ditingkatkan melalui alat-alat teknologi seperti komputer, kamera digital, scanner dan Sistem Komputerisasi Haji Terpadu (SISKOHAT) karena melihat calon jamaah haji yang sangat antusias.

Fungsi dari sarana dan prasarana ini dapat berbeda sesuai dengan lingkup dan penggunaannya, namun memiliki tujuan yang sama yaitu untuk mencapai suatu proses atau hasil yang diharapkan sesuai dengan rencana, adapun fungsi utama dari fasilitas saranan dan prasarana memiliki tujuan diantaranya yaitu, dapat menciptakan kenyamanan, dapat menciptakan kepuasan, dapat mempercepat suatu proses kerja, dapat mempermudah proses kerja, dapat meningkatkan produktivitas dan hasil yang lebih berkualitas. Kualitas pelayanan berupa kondisi wujud ini merupakan bentuk dari kualitas pelayanan yang nyata yang dapat memberikan apresiasi, membentuk imej yang positif bagi setiap individu yang dilayani dan suatu penilaian dalam menentukan kemampuan dari penembangan pelayanan tersebut.

\section{Responsiveness (Ketanggapan) dalam Membantu dan Menyediakan Pelayanan}

Suatu kebijakan untuk membantu dan memberikan pelayanan yang cepat dan tepat kepada pelanggan yaitu dengan penyampaian yang jelas. Setiap lembaga atau organisasi sangat menyadari bahwa pentingnya kualitas pelayanan ketanggapan (responsiveness) atas pelayanan yang diberikan oleh suatu lembaga kepada jamaah haji,seseorang yang mendapatkan pelayanan sangatlah membutuhkan penjelasan atas pelayanan yang diberikan oleh suatu lembaga agar pelayanan tersebut jelas dan dapat dimengerti, maka dari itu daya tanggap memiliki peranan penting atas pelayanan yang diberikan kepada setiap jamaah.Ketanggaan yang diberikan oleh suatu lembaga atau organisasi tentunya sangatlah disenangi oleh setiap calon jamaah haji yang akan melaksanakan ibadah haji, sebagaimana sifat seorang manusia pada umunya bahwa manusia akan senang apabila mendapatkan perhatian, dilayani dengan cepat dan membantu pada saat mengalami masalah, apabila pelayanan ketanggapan ini diberikan dengan baikatas penjelasan yang bijaksana dan mendetail secara tidak langsung penjelasan tersebut dapat dimengerti oleh calon jamaah yang telah mendapatkan pelayanan, maka secara langsung pelayanan ketanggapan ini dianggap berhasil dan menjadi suatu bentuk keberhasilan prestasi kerja. 
Responsiveness ini merupakan kesediaan dan kesadaran untuk merespon setiap calon jamaah haji yang membutuhkan layanan dengan cepat, tepat, cermat dan merespon setiap keluhan yang disampaikan oleh calon jamaah haji (Hardiyansyah, 2011: 231). Untuk mengetahui bahwa daya tanggap yang diberikan oleh suatu lembaga atau organisasi itu baik maka dapat diukur dengan adanya indikator ketanggapan seperti merespon setiap calon jamaah haji yang ingin mendapatkan pelayanan dan kesigapan pegawai dalam melakukan pelayanan dengan cepat dalam memberikan ketanggapan terhadap calon jamaah haji penyelenggaraan haji dan umrah tentunya harus menerapkan indicator tersebut guna mempermudah dalam memberikan pelayanan yang dihadapi oleh calon jamaah haji.Berdasarkan dari hasil wawancara dengan bapak H. Odang selaku kepala seksi penyelenggaraan haji dan umrahbeliau memaparkan bahwa:

"dalam memberikan pelayanan terhadap calon jamaah haji tentunya penyelenggaraan haji dan umrah terlebih mengawali dengan senyum, menyapa dan melayani setiap permasalahan yang dihadapi oleh calon jamaah haji, tentunya dalam menanggapi permasalahan atau keluhan tersebut harus sesuai dengan prosedur keluhan atau permasalahan yang dihadapi" (wawancara pada hari senin, 4 Juni 2018).

Disamping itu bapak H. Bahar selaku staff penyelenggaraan haji dan umrah juga mengutarakan tentang kesigapan staff-staff yang adadi penyelenggaraan haji dan umrahdalam memberikanpelayanan kepada calon jamaah haji di kementerian agama kabupaten karawang:

"untuk menanggapi keluhan atau permasalahan tersebut seksi penyelenggaraan haji dan umrah memiliki staff yang masing-masing akan menanggapi keluhan dari calon jamaah haji tersebutsesuai dengan bidangnya untuk dapat memberikan pelayanan pada setiap calon jamaah haji sendiri, serta dapat memberikan pelayanan secara sigap, cepat dan tepat dengan adanya faktor penunjang dari pelayanan haji satu atap dalam memberikan pelayanan terhadap calon jamaah haji" (wawancara pada hari senin, 4 Juni 208).

Adapun dalam meningkatkan pelayanan yang dilakukan oleh penyelenggaraan haji dan umrah (PHU)dalam memberikan daya tanggapkepada calon jamaah haji adalah dengan meningkatkan pelayanan jamaah haji melalui sistem komputerisasi haji terpadu dan memberikan pembinaan kepada calon jamaah haji.Maka dari itu dengan adanya daya tanggap dapat memberikan pelayanan secara maksimal terhadap calon maupun jamaah haji ditambah dengan adanya faktor inovasi dari pelayanan haji satu atap yang dapat membantu proses pelayanan dengan cepat dan sigap kepada calon jamaah haji. Dari uraian diatas sudah jelas bahwa ketanggapan merupakan indikator yang penting dalam 
memberikan pelayanan terhadap calon jamaah haji, secara jamaah akan merasa senang apabila keluhan jamaah haji ini dapat dilayani dengan cepat, tepat dan sigap oleh staff pelayanan haji.

Kualitas pelayanan daya tanggap adalah suatu bentuk pelayanan dalam memberikan penjelasan, agar orang yang diberi pelayanan tanggap dan menanggapi pelayanan yang telah diterima, sehingga diperlukan adanya unsur kualitas layanan daya tanggap yaitu sebagai berikut: Memberikan penjelasan secara bijaksana sesuai dengan bentuk-bentik pelayanan yang dihadapi. Memberikan penjelasan mendetail yaitu bentuk penjelasan yang substantifdengan dengan persoalan pelayanan yang dihadapi yang bersifat jelas, trasparan, singkat dan dapat dipertanggungjawabkan. Memberikan membinaan atas bentuk-bentuk pelayanan yang diangggap masih kurang atau belum sesuai dengan syarat-syarat atau prosedur pelayanan yang ditunjukan. Mengarahkan setiap bentuk pelayanan dari individu yang dilayani untuk menyiapkan, melaksanakan dan mengikuti berrbagai ketentuan pelayanan yang harus dipenuhi. Membujuk orang yang dilayani apabila menghadapi suatu permasalahan yang dianggap bertentangan, berlawanan atau tidak sesuai dengan prosedur dan ketentuan yang berlaku (Margaretha, 2003: 163).

\section{Assurance (Jaminan) yang diberikan dalam Meningkatkan Kepuasan}

Jaminan merupakan kemampuan sebuah lembaga dalam memberikan jaminan baik dari segi jaminan ketepatan waktu, biaya, legalitas serta kepastian besarnya biaya dalam proses pelayanan (Hardiyansyah, 2011: 232). Dalam sebuah lembaga atau organisasi, jaminan merupakan suatu hal yang sangat penting dalam membangun sebuah keyakinan dan kepercayaan antara pemberi jasa maupun pengguna jasa, jaminan sendiri tidak hanya dengan atasan kepadabawahan ataupun sebaliknya tetapi jaminan ini dapat melibatkan kepada calon jamaah haji, apabila kepercayaan yang diberikan oleh jamaah kepada suatu lembaga tidak digunakan dengan sebaik-baiknya maka akan hilang kepercayaan yang telah diberikan oleh calon jamaah kepada sebuah lembaga atau organisasi. Jaminan ini merupakan suatu pengetahuan, kesopansantunan dan kemampuan para staff dalam menumbuhkan rasa percaya para jamaah haji kepada sebuah lembaga atau organisasi. Hal ini sebagaimana diutarakan oleh bapak H. Odang selaku seksi penyelenggaraan haji dan umrah:

“jaminan kepercayaan yang diberikan oleh penyelenggaraan haji dan umrah yaitu dengansalah satunya ialah menjaga keuangan penyetoran jamaah, jaminan pendaftaran dan masih banyak lagi jaminan yang diberikan" (wawancara pada hari senin, 4 Juni 2018).

Agar kepercayaan tetap terjaga maka perlu adanya komunikasi yang baik dan efisien antara suatu lembaga atau organisasi dengan calon jamaah haji, 
adanya kualitas, kredibilitas ini meliputi hal yang berhubungan dengan kepercayaan kepada sebuah lembaga atau organisasi seperti reputasi, prestasi dan sebagainya, keamanan, kompetensiini meliputi keterampilan dan pengetahuan yang dimiliki oleh seorang staff dalam memberikan pelayanan, dan sopan santun ini meliputi keramahan dan perhatian dari sikap para staff saat melayani. Adapun cara menjaga kepercayaan antara calon jamaah haji dengan lembaga atau organisasi diantaranya sebagai berikut: Ketebukaan (openness) yaitu sikap yang dapat menerima masukan dari orang lain. Empati (emphaty) yaitu perhatian suatu lembaga atau organisasi kepada jamaah haji. Sikap Mendukung (supportiveness) yaitu antara lembaga dengan calon jamaah haji mampu saling berkomunikasi dan berkomitmen untuk mendukung terlaksananya penyelenggaraan ibadah haji yang baik dan sukses. Sikap Positif (positiveness) ini terbagi menjadi du acara yaitu, sikap positif untuk dirinya sendiri (lembaga) dan sikap positif yang mendorong orang menjadi teman berinteraksi kepada para calon jamaah haji. Kesetaraan (equality) yaitu tidak adanya perbedaan posisi dan status antara lembaga dengan jamaah (Kusnawan, A., Rahman, A., Lukman, D. \& Dulwahab, E. 2017: 282).

Berikut adalah jaminan yang di berikan oleh penyelenggaraan haji dan umrah kementerian agama untuk meningkatkan kepuasan terhadap calon jamaah haji diantaranya sebagai beikut:

Pertama, jaminan administrasi yaitu jaminan berupa ketepatan waktu dan keamanan yang diberikan oleh penyelenggara ibadah haji kepada calon jamaah haji, setelah calon jamaah haji telah mendaftarkan dirinya untuk menjadi calon jamaah hajidengan ketentuan calon jamaah haji telah memenuhi persyaratan pendaftaran yang telah ditentukan oleh pihak penyelenggara ibadah haji dan umrah, maka dengan persyaratan itu semua akan mempermudah dalam pengelolaan data untuk mendapatkan nomor porsi untuk keberangkatan haji danjaminan tersebut tidak akan hilang. Tidak hanya jaminan administrasi tetapi jaminan keamanan administrasi yang dilakukan oleh calon jamaah haji juga ada penjaminan seperti jaminan penyelamatan uang jamaah haji, jamianan administrasi ini bisa kembali jika calon jamaah haji meninggal di tanah air atau mengundurkan diri karena beralasan kesehatan, atau membatalkan pendaftaran haji yang disebabkan oleh hal-hal yang lain.

Kedua, jaminan keilmuan, jaminan keilmuan ini dilakukan dengan memberikan bimbingan manasik kepada calon jamaah haji. Peraturan tentang pembinaan ibadah haji dan umrah ini merujuk pada undang-undang nomor 13 tahun 2008 tentang penyelenggaraan ibadah haji pembinaan ini diarahkan agar terwujudnya calon jamaah haji yang mandiri, yaitu kemampuan calon jamaah haji dalam memahami dan melaksanakan tata cara ibadah haji. Adapun jumlah bimbingan manasik yang diselenggarakan sebanyak delapan kali pertemuan, yaitu 
enam kali di tingkat kecamatan yang diselenggarakan oleh Kantor Urusan Agama (KUA) dengan narasumber kepala kementerian agama kabupaten karawang, kepala seksi penyelenggaraan haji dan umrah, kepala Kantor Urusan Agama (KUA), Majelis Ulama Indoneisa (MUI) kecamatan dan tokoh agama setempat dan dua kali di tingkat kabupaten atau kota dengan narsumber dari kanwil kementerian agama prov jabar, kepala kantor kementerian agama kabupaten karawang dan Majelis Ulama Iindonesia (MUI) kabupaten karawang dan bimbingan mansikoleh kelompok bimbingan ibadah haji $(\mathrm{KBIH})$ bimbingan manasik ini dilaksanakan sebanyak lima belas kali pertemuan dengan narasumber kepala kementerian agama, kepala seksi penyelenggaraan ibadah haji, pembimbing kelompok bimbingan ibadah haji yang bersertifikat, kepala puskesmas setempat dan tokoh masyarakat.Adapun kelompok bimbingan ibadah haji yang melaksanakan bimbingan manasik haji diantaranya iala, At-taubah kaum, mathlaul anwar, al-ittihad, darul fikri, al-madinah, nursyifa, an-nida, annihayah, asshidiqiyah, al-mansyuriah, lampu iman, al-ma'ruf, darusalam dan NU batujaya.

Bimingan manasik ini adalah sebuah pelatihan atau tata cara ibadah haji dari keseluruhan rangkaian ibadah haji yang dituangkan dalam manasik guna mempermudah calon jamaah haji dalam memahami kailmuan baik secara teoritis dan praktis sehingg diharapkan menjadi calon jamaah haji yang mandiri dalam melaksanakan ibadah haji dengan baik dan benar sesuai dengan tuntunan rasulullah saw.

Untuk jaminan keilmuan ini kompetensi calon jamaah haji dalam keilmuan tentang penyelenggaraan ibadah haji mengenai pengetahuan dan wawasan calon jamaah haji sangatlah beragam, diantaranya yaitu: ada calon jamaah haji yang sudah memahami dan mengetahui tentang penyelenggaraan ibadah haji yaitu seperti seorang ulama. Ada calon jamaah haji yang sama sekali tidak mengetahui tentang penyelenggaraan ibadah haji seperti usia yang sudah tua dan susah dalam berkomunikasi dan Ada karakter calon jamaah haji yang melek dengan pengetahuan dan wawasan tentang ibadah haji tetapi memiliki karakter yang cenderung unik seperti sok tahu, sok pinter karena ingin dilihat oleh orang lain dan cenderung arogan (Kusnawan, A., Rahman, A., Lukman, D. \& Dulwahab, E. 2017: 281).

\section{PENUTUP}

Berdasarkan hasil penelitian dan pembahasan yang telah dibahas dan dilaksanakan pada bab-bab sebelumnya, maka penulis dapat mengambil kesimpulan dari pembahasan yang penulis bahas mengenai optimalisasi pelayanan haji dalam meningkatkan kepuasan jamaah, berdasarkan data yang diperoleh penulis maka dapat ditarik kesimpulan sebagai berikut: 
Pertama, fasilitas pelayanan sarana dan prasaranan yang terdapat di kementerian agama kabupaten karawang terutama di bidang Penyelenggaran Haji dan Umrah (PHU) sudah cukup baik, fasilitas saranan dan prasaranan yang diberikan kepada calon maupun jamaah haji seperti kenyamanan tempat dalam melakukan pelayanan dan penggunaan alat-alat teknologi yang sudah memadai seperti komputer, scanner dan kamera digital untuk kelengkapan dalam memberikan pelayanan kepada calon jamaah haji serta ditambah dengan adanya penunjang pelayanan haji satu atap yang dapat memberikan kemudahan kepada calon jamaah haji dalam melakukan pelayanan, sehingga waktu yang digunakan dalam memberikan pelayanan kepada jamaah haji tidak terlalu lama.

Kedua, ketanggapan yang dilakukan oleh penyelenggaran ibadah haji dan umrah dalam membantu melayani terhadap calon jamaah haji yaitu dengan menempatkan staff-staff pegawai sesuai dengan bidang keahlian yang dimiliki agar dapat mempermudah dan mempercepat dalam proses menanggapi pelayanan kepada calon maupun jamaah haji.

Ketiga, jaminan yang diberikan oleh bidang penyelenggaraan haji dan umrah kepada calon jamaah haji untuk meningkatkan kepuasan jamaah haji diantaranya yaitu, adanya jaminan administrasi, jaminan keamanan dan jaminan keilmuan. Jaminan administrasi ini meliputi ketepatan waktu dan keamanan yang diberikan kepada calon jamaahhaji oleh penyelenggaraan haji dan umrah untuk mengurus semua administrasi baik dari pendaftaran haji, pemberangkatan samapi perpulangan jamaah haji. Jaminan keilmuan yang diberikan oleh penyelenggaraan haji dan umrah kepada calon jamaah haji ialah dengan memberikan keilmuan melalui bimbingan manasik haji baik yang diselenggarakan oleh Kelompok Bimbingan Ibadah Haji (KBIH), bimbingan manasik oleh tingkat kecamatan yang diselenggarakan oleh Kantor Urusan Agama (KUA), maupun bimbingan manasik oleh tingkat kabupaten yang diselenggarakan oleh kementerian agama itu sendiri.

Berdasarkan hasil penelitian yang telah dijelaskan, maka penulis akan memberikan sedikit saran terkait tentang pelayanan haji dalam meningkatkan kepuasan jamaah yang ada di penyelenggaraan haji dan umrah, yakni secara keseluruhan pelayanan yang diberikan oleh bidang Penyelenggaraan Haji dan Umrah (PHU) kepada calon jamaah haji sudah cukup baik serta sudah memenuhi dimensi dari kualitas pelayanan, namun staff penyelenggaraan haji dan umrah harus tetap menjaga kualitas pelayanan, seperti tetap menjaga keramahan dan memberikan pelayanan dengan baik terhadap calon jamaah haji dan bidang penyelenggaraan haji dan umrah harus tetap mempertahankan atau lebih meningkatkan lagi kualitas di bidang pelayanan karena sangat berpengaruh terhadap pelayanan yang akan diberikan kepada calon jamaah haji sehingga 
R. Wildayati, D. Solahudin, dan Arif Rahman

dengan meningkatan pelayanan tersebut calon jamaah haji akan merasa puas terhadap pelayanan yang diberikan oleh Penyelenggaran Haji dan Umrah (PHU).

\section{DAFTAR PUSTAKA}

Fanham, A.M. (2015) Penyelenggaraan Ibadah Haji, Masalah dan Penanganannya, Jurnal Kajian; Menjembatani Teori dan Persoalan dalam Perumususan Kebijakan, 20 (3): 201-2018.

Hardiyansyah. (2011). Kualitas Pelayana Publik, Yogyakarta: Gaya Media.

Irawan, H. (2004). Kepuasan Pelayanan Jasa, Jakarta: Erlangga.

Jaya, F. (2013) Analisis Tingkat Kepuasan Jemaah Haji Kota Medan Terhadap Pelayanan Haji Tahun 2012, Jurnal Ekonomi dan Keuangan, 1 (11): 37-45.

Khoiruddin, H., Hanafi, I., dan Rozikin, M. (2015) Pengaruh Reformasi

Organisasi Pengelolaan Pelayanan Haji Terhadap Kepuasan Jamaah Haji, Jurnal Administrasi Publik, 3 (12): 2089-2093

Kusnawan, A., Ramhan, A., Lukman, D. \& Dulwahab, E. (2017) Manajemen

Mutu Input Kelompok Bimbingan Ibadah Haji Indonesia. Ilmu Dakwah:

Acamedis Journal gor Homiletic Studies, 11(2) 277-292.

Margaretha. (2003). Kualitas Pelayanan Teori dan Aplikasi, Jakarta: Mandar Maju.

Moenir. (2005). Manajemen Pelayanan Umum di Indonesia, Jakarta: Bumi Aksara.

Nidzam, A. (2015) Efektivitas Prosedur Pendaftaran Haji melalui Rakayasa

Ulang Proses Bisnis, Penamas; Jurnal Penelitian Keagamaan dan Kemasyarakatan, 28 (3): 351-532.

Rahmayanti, N. (2010). Manajemen Pelayanan Prima, Yogyakarta: Graha Ilmu.

Ramadoni (2013). Pelayanan KBIH Darut Tauhid dalam Memfasilitasi Calon Jamaah Haji. Skeripsi, Prodi Manajemen Dakwah, UIN Bandung.

Rewansyah, A. (2011). Kepemimpinan dalam Pelayanan Publik, Jakarta: STAIALAN.

Sulistyowati, M.\& Hreawati, N. (2019). Strategi Meningkatkan Kepuasan dan Loyalitas Nasabah dengan Optimalisasi Kualitas Pelayanan, Penanganan Komplain dan Fasilitas Teknologi di Bank Mandiri Syariah Cabang Solo. ProBank: Jurnal Ekonomi Dan Perbankan, 4(1), 15-26.

Sungkar \& Fitriyani (2016). Optimalisasi Layanan Untuk Meningkatkan

Kepuasan Pelanggan Melalui Akses Internet Menggunakan Radius Server. JICT -STMIK IKMI Cirebon, 15 (2), 37-42.

Susilawati, I., Sarbini, A., dan Setiawan, A.I. (2016) Implementasi Fungsi Manajemen dalam Pelayanan Bimbingan Manasik Haji di Kelompok

Bimbingan Ibadah Haji, Tadhbir: Jurnal Manajemen Dakwah, 1 (2): 190-206.

Tjiptono, F. (2006). Manajemen Jasa, Yogyakarta: Andi.

Taufiqurrochman. (2011). Manasik Haji \&Ziarah Spiritual, Malang: UIN Maliki Press. 
Optimalisasi Pelayanan Haji dalam Meningkatkan Kepuasan Jamaah

Anida (Aktualisasi Nuansa Ilmu Dakwah) 17(2) (2017) 165-182 